BBA $55^{649}$

\title{
PHOSPHATIDATE SYNTHESIS BY sn-GLYCEROL-3-PHOSPHATE ACYL- TRANSFERASE IN PIGEON LIVER PARTICLES
}

DAVID R. HUSBANUS* AND WILLIAM E. M. LANDS

Department of Biological Chemistry,

The University of Michigan, Ann Arbor, Mich. 48104 (U.S.A.)

(Received August 5 th, I969)

\section{SUMMARY}

The properties of acyl-CoA: sn-glycerol-3-phosphate acyltransferase (EC 2.3.I.I5) from pigeon liver particles have been studied. The apparent $K_{m}$ for $s n$ glycerol 3-phosphate was $50 \mu \mathrm{M}$. Acyl-CoA inhibited the enzyme at concentrations exceeding 6o $\mu \mathrm{M}$. This inhibition can be overcome by adding extra protein. The enzyme was inhibited by thiol-binding agents. Protection from thiol-binding agents is achieved by preincubation of the enzyme with acyl-CoA. The amount of the thiol group protected per mg enzyme protein was estimated by adding radioactive $N$ ethylmaleimide in the presence of glycerol phosphate. No evidence was obtained for required sulfhydryl groups other than those protected by acyl-CoA. In the presence of bovine serum albumin, several different acyl-CoA derivatives were esterified to $s n$-glycerol 3-phosphate at very similar rates.

\section{INTRODUCTION}

The first step in the formation of glycerides and phosphoglycerides is the acylation of $s n$-glycerol 3-phosphate. The enzyme that catalyzes this reaction, glycerophosphate acyltransferase (acyl-CoA : sn-glycerol-3-phosphate aryltransferase, EC 2.3.I.I5), appears to be of universal occurrence, having been found in mammalian liver particles ${ }^{\mathbf{1}, 2}$, mammalian brain $^{3}$, leaf tissue of plants ${ }^{4,5}$, yeast ${ }^{6}$ and bacteria ${ }^{7,8}$. It is a particulate enzyme and its activity can be inhibited by thiol-binding agents ${ }^{6,9}$. The properties of the enzymes so far isolated show that the enzyme from yeast requires acyl-CoA as an obligatory acyl donor ${ }^{6}$, but activity from Escherichia coli and Clostridium butyricum can also use the acyl group attached to acyl carrier protein ${ }^{7,10}$. In mammalian systems, the enzyme appears to require acyl-CoA as the acyl donor (refs. I, 3, 9, II). However, the intervention of an acyl carrier protein has not been ruled out, and the nature of the thiol group that causes the loss of enzyme activity when combined with thiol-binding agents is not yet elucidated. The purification of

* Present address: Unilever Research Laboratory, Colworth House, Sharnbrook, Bedford, England. 
the enzyme has not progressed very far. MÅRTENSSON AND KANFER ${ }^{3}$ have reported a solubilization and partial purification of the enzyme from brain tissue by using a special homogenization technique. In this paper we report on the properties of the activity present in pigeon liver particles.

\section{MATERIALS AND METHODS}

\section{Preparation of pigeon liver particles}

Crossbred pigeons, both male and female, were obtained from a local supplier. They were fed a standard pigeon chow. All animals were allowed free access to food and water until they were killed. The liver was rapidly removed, cooled to $0^{\circ}$ and homogenized in 9 vol. of $0.25 \mathrm{M}$ sucrose and I $\mathrm{mM}$ EDTA. The particulate fraction separating at $5000 \times g$ for ${ }_{5} 5$ min was discarded. The particles sedimenting at $7^{8} 5^{\circ 0} \times$ $g$ for 60 min were used as the source of the enzyme. The particles were washed once by suspending and recentrifuging in $0.25 \mathrm{M}$ sucrose containing I mM EDTA. All operations were carried out at $0-4^{\circ}$. The particles were either used on the same day or were stored at $-\mathrm{I} 5^{\circ}$. Experiments showed that storage at $-\mathrm{I} 5^{\circ}$ resulted in some loss of activity but this could be minimized by making the solution Io $\mathrm{mM}$ in dithiothreitol.

\section{Chemicals}

$s n-\left[\mathrm{I}(3)^{-14} \mathrm{C}\right]$ Glycerol was obtained from the Volk Radiochemica] Company and glycerol-3-phosphate dehydrogenase from Calbiochem. sn-Glycerol 3-phosphate was prepared from glycerol and ATP as described previously ${ }^{12}$. The amounts of $s n$ glycerol 3-phosphate formed was estimated by the method of HoHORST ${ }^{13}$ using $s n$ glycerol-3-phosphate dehydrogenase. sn-glycerol I(3)- $\left[{ }^{32} \mathrm{P}\right]$ phosphate was prepared by the method of McMurray et al. ${ }^{14}$. Acyl-CoA derivatives were prepared by the method of LANDS et al. ${ }^{15}$ from acyl chlorides obtained from the Hormel Institute. The quantity of acyl-CoA present was calculated from the extinction coefficients at 260 and $232 \mathrm{~m} \mu$ (ref. I6) except with the unsaturated acyl derivatives which were estimated by the extent of their reaction in the acyl-CoA:I-acylglycerophosphorylcholine acyltransferase reaction described by IANDS AND HART ${ }^{9}$.

$N$-Ethylmaleimide was obtained from Calbiochem and $\left(\left[\mathrm{I}-{ }^{14} \mathrm{C}\right]-N\right.$-ethyl maleimide from Schwarz Bio Research, Inc. Dithiothreitol was obtained from Calbiochem.

Protein concentration was estimated using the extinction coefficients at 260 and $280 \mathrm{~m} \mu$ derived from the data of WARBURG AND CHRISTIAN ${ }^{17}$.

\section{Assay of enzyme activity}

The assay mixture had a final volume of $0.35 \mathrm{ml}$. It contained $20 \mu$ moles of Tris chloride buffer ( $\mathrm{pH} 8.0)$, roo nmoles of $s n$-[14 $\mathrm{C}]$ glycerol 3 -phosphate, Io nmoles of stearoyl-CoA and $\mathrm{I} \mathrm{mg}$ of particulate protein. The reaction was allowed to proceed for $2 \mathrm{~min}$ and then $7 \mathrm{ml}$ of chloroform-methanol $(2: \mathrm{I} \mathrm{v} / \mathrm{v})$ was added, follower by $\mathrm{I} .4 \mathrm{ml}$ of $0.03 \mathrm{M} \mathrm{HCl}$ containing $2 \%$ acetic acid. The mixture was shaken, the two phases allowed to separate, and the upper phase removed along with the denatured protein at the interface. The lower phase was washed twice with the upper phase of a mixture of chloroform-methanol $0.03 \mathrm{M} \mathrm{HCl}$ containing acetic acid (20: I0:7.5 
by vol.). The washings were removed and the lower phase evaporated prior to counting in the dioxane scintillation counting system of SNYDER ${ }^{18}$.

\section{RESULTS}

The enzyme esterified sn-glycerol 3-phosphate at a rate that was linear with time for about $4 \mathrm{~min}$ (Fig. IA) when the esterification rate then fell off. At this time only $60 \%$ of the acyl-CoA had been used up in the reaction so the decrease in rate is unlikely to be due to lack of substrate. The amount of acyl-CoA hydrolyzed by acyl-CoA hydrolase was determined by the spectrophotometric technique using $5,5^{\prime}$-dithio-bis-(2-nitrobenzoic acid) ${ }^{9}$. The rate of hydrolysis catalyzed by these preparations was very low.
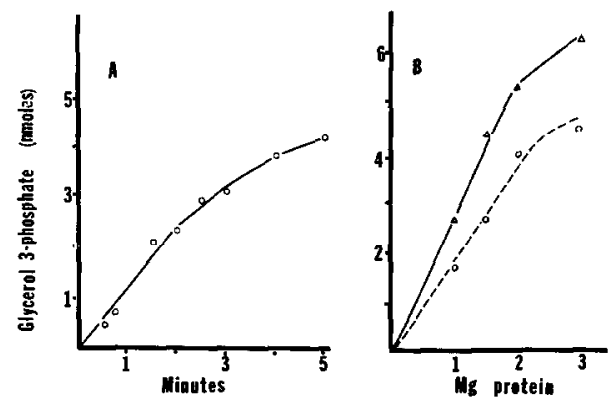

Fig. I. A. Time course of the reaction yielding phosphatidate. The standard assay mixture was used. The final volume, $0.35 \mathrm{ml}$, contained $20 \mu$ moles of Tris chloride buffer $(\mathrm{pH} 8.0)$, I mg of enzyme protein, Ioo nmoles of $s n-\left[{ }^{14} \mathrm{C}\right]$ glycerol 3 -phosphate and 13.3 nmoles of palmitoyl-CoA, which was added last. B. Effect of microsomal protein. The reaction mixtures were similar to those in A with protein varied as shown. $\triangle-\triangle$, results after 4 -min incubation. $0--0$, results after 2 -min incubation.

The amount of product formed with varying levels of enzyme is shown in Fig. IB. Linearity was maintained only over a narrow range of protein concentrations from $\mathrm{I}$ to $2 \mathrm{mg}$. Addition of more protein caused a non-linear increase in the rate of acylation. This may be due either to the binding of palmitoyl-CoA to the extra protcin added or to the cxhaustion of the acyl-Co $A$ substratc. With a 4-min incubation and $3 \mathrm{mg}$ of enzyme protein, $90 \%$ of the palmitoyl-CoA had been used up, calculating that diacyl-sn-glycerol 3-phosphate was the product.

\section{Identification of the product as diacyl-sn-glycerol 3-phosphate}

The product from the standard reaction mixture described above was extracted and the $\mathrm{pH}$ adjusted to 7.0-8.0, as indicated by $\mathrm{pH}$ paper, by addition of triethylamine. The triethylamine salts of the reaction products were chromatographed on glass fibre paper impregnated with silicic acid (Gelman Inc., Ann Arbor, Mich.) with a developing solvent of chloroform-methanol-9.73 $\mathrm{M} \mathrm{NH}_{4} \mathrm{OH}$ (80:18:2.4, by vol.). $90 \%$ of the isotope in the product applied to the paper chromatographed as one spot. This radioactive spot cochromatographed with authentic diacylglycerol phosphate. A small amount of isotope was present at the solvent front $(I-5 \%)$. At the origin, where glycerol phosphate is found, $6 \%$ of the isotope was detected. The only evidence for the presence of monoacyl-sn-glycerol 3-phosphate was a slight tailing of the diacyl spot, but this tailing contained no more than $4 \%$ of the total isotope 
present in the product. Further evidence for the formation of the diacyl derivative was obtained by submitting the triethylamine salt of the product obtained above to phosphatidate phosphohydrolase (EC 3.I.3.4). The enzyme was prepared from fresh chicken livers by the procedure described by Sмiтн et al. ${ }^{19}$. The triethylamine salts of the products of the enzyme reaction were evaporated to dryness under a stream of $\mathrm{N}_{2}$ in screw-capped vials and r.o ml of $0.02 \mathrm{M}$ Tris chloride ( $\mathrm{pH} \mathrm{8.0)}$ was added. The $\mathrm{pH}$ was adjusted to 6.3-6.7 with I.o M maleic acid. Crude phosphatidate phosphohydrolase and $1.0 \mathrm{ml}$ of diethyl ether were added and the reaction mixture incubated at $37^{\circ}$ for $2 \mathrm{~h}$ with shaking. The reaction products were isolated by addition of $\mathrm{I} 5 \mathrm{ml}$ of chloroform-methanol $(2: \mathrm{I}, \mathrm{v} / \mathrm{v})$ and $3 \mathrm{ml}$ of water. The lower phase was taken to dryness and applied to a silicic acid column. The neutral lipids were eluted with benzene-ether $(\mathrm{I}: \mathrm{I}, \mathrm{v} / \mathrm{v})$ and ether, and the phospholipids with methanol. Between 93 and $97 \%$ of the counts were recovered as neutral lipid and $3-6 \%$ were eluted as phospholipids. The neutral lipid was fractionated by thin-layer chromatography as described by HiLL et al. ${ }^{12}$. The monoglyceride fraction contained $6-\mathrm{I} 6 \%$ of the recovered isotope, the diglyceride fraction $84-94 \%$, and the triglyceride fraction less than $3 \%$. The diglyceride fraction was shown to cochromatograph with I,2diacylglycerol in a small number of samples examined to check this point. These experiments identifying the products were done with phosphatidate prepared by incubating stearoyl-CoA, oleoyl-CoA, linoleoyl-CoA and a mixture of stearoyl and lineoyl-CoA with $s n-\left[{ }^{14} \mathrm{C}\right]$ glycerol 3-phosphate ${ }^{12}$. From these data we conclude that the major product of the reaction is diacyl-sn-glycerol 3-phosphate.

\section{The effect of substrate concentration on the reaction rate}

The substrate concentration curve for sn-glycerol 3-phosphate shows a typical saturation phenomenon (Fig. 2) indicating an apparent $K_{m}$ for $s n$-glycerol 3-phosphate of $5^{\circ} \mu \mathrm{M}$. This is similar to the value calculated from the results of TzUR et al." for rat liver but is lower than that for either the yeast enzyme ${ }^{6}$ or the $E$. coli enzyme ${ }^{7}$.
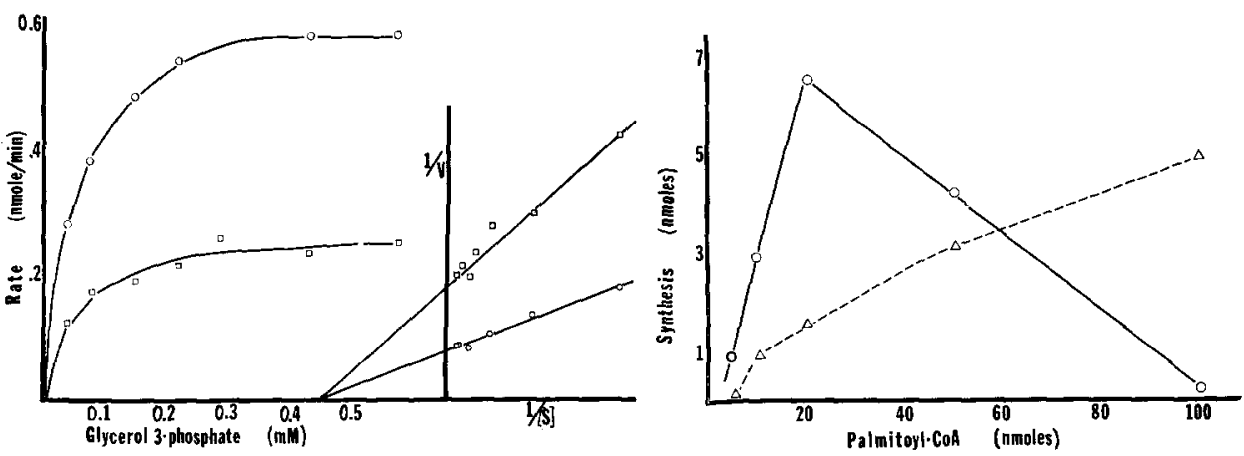

Fig. 2. Effect of sn-glycerol 3-phosphate concentration on the rate of formation of phosphatidic acid. The final volume $(0.35 \mathrm{ml})$ contained $20 \mu$ moles of Tris chloride buffer $(\mathrm{pH} 8.0)$, I $\mathrm{mg}$ of protein with either 50 nmoles of palmitoyl-CoA and varied amounts of glycerol phosphate added last ( $\square-\square)$, or varied amounts of glycerol phosphate and 10 nmoles of palmitoyl-CoA added last $(0-0)$.

Fig. 3. The effect of palmitoyl-CoA content on the amount of phosphatidic acid formed by the particulate enzyme with and without added bovine serum albumin. $0-0$, results when a normal reaction mixture $(0.35 \mathrm{ml})$ was used with the $\mathrm{I} .0 \mathrm{mg}$ of enzyme added last; $\triangle--\Delta$, results when $5 \mathrm{mg}$ of bovine serum albumin were present, and glycerol phosphate was added last. 
The value given by FALLON AND LAMB $^{2}$ for rat liver is $6.7 \mathrm{M}$, indicating a much lower affinity for $s n$-glycerol 3-phosphate with their enzyme preparation. The results in Fig. 2 show that the $K_{m}$ value is independent of the inhibition caused by higher levels of acyl-CoA.

The substrate concentration curve for acyl CoA shows a marked inhibition at concentrations above $60 \mu \mathrm{M}$ (Fig. 3). This is similar to the inhibition of other $s n$ glycerol-3-phosphate acyltransferases studied. The inhibition can be overcome by adding more protein (Table I). BRANDES et al.11 observed a similar phenomenon with the rat liver enzyme as did MÅRTENSSON AND KANFER ${ }^{3}$ with the enzyme from rat brain. We found that bovine serum albumin and $N$-ethylmaleimide-treated microsomes were effective in relieving the inhibition, but boiled microsomes were less effective.

\section{TABLE I}

THE ABILITY OF ADDED PROTEIN TO OVERCOME THE INHIBITION CAUSED BY PREINCUBATION OF THE ENZYME WITH PALMITOYL-COA

Enzymatically active particles (1.8 mg protein) were preincubated with the various protein additions in the presence of $20 \mu$ moles of phosphate buffer ( $\mathrm{pH} 6.5$ ), $5 \mu$ moles of dithiothreitol and 42 nmoles of palmitoyl-CoA in a final volume of $0.65 \mathrm{ml}$. After $5 \mathrm{~min}$, the reaction was initiated by adding Ioo nmoles of $s n$-glycerol 3 -phosphatc. $\Lambda$ fter Io min of reaction, $12 \mathrm{ml}$ of chloroform -methanol $(2: \mathrm{I}, \mathrm{v} / \mathrm{v})$ were added and the radioactive products were determined by the standard procedure.

\begin{tabular}{ll}
\hline Extra protein added & $\begin{array}{l}\text { sn- }\left[{ }^{14} \mathrm{C}\right] \text { Glycerol 3-phosphate } \\
\text { converted to phosphatidate } \\
(\text { nmoles })\end{array}$ \\
\hline None & 0.068 \\
$3.6 \mathrm{mg}$ boiled microsomes & 0.16 \\
$3.6 \mathrm{mg}$ active enzyme protein & 0.80 \\
(per I.8 mg enzyme protein) & $(0.27)$ \\
$3.6 \mathrm{mg}$ bovine serum albumin & $0.5 \mathrm{I}$ \\
$3.6 \mathrm{mg} N$-ethylmaleimide-treated & \\
microsomes & $0.5 \mathrm{I}$ \\
\hline
\end{tabular}

\section{TABLE II}

EFFECT OF THE ORDER OF ADDITION OF SUBSTRATES ON THE AMOUNT OF PHOSPHATIDIC ACID FORMED IN 5 MIN

Final volume of assay tubes was $0.35 \mathrm{ml}$, containing $20 \mu$ moles of Tris chloride (pH 8.o), Ioo nmoles of $s n$ - $\left[{ }^{14} \mathrm{C}\right]$ glycerol $3-$ phosphate, $1.0 \mathrm{mg}$ enzyme protein, and various amounts of palmitoylCoA. The reaction was stopped after $5 \mathrm{~min}$ by the addition of $7 \mathrm{ml}$ of chloroform-methanol $(2: I, V / v)$.

\begin{tabular}{|c|c|c|c|}
\hline \multirow{2}{*}{$\begin{array}{l}\text { Palmitoyl-CoA } \\
\text { (nmoles) }\end{array}$} & \multicolumn{3}{|c|}{ Reagent added last (nmoles $/ 5 \mathrm{~min}$ ) } \\
\hline & Glycerol phosphate & Enzyme & Palmitoyl-Co $A$ \\
\hline \multicolumn{4}{|c|}{ (a) Enzyme alone } \\
\hline 5 & 0.03 & $0.9 \mathrm{I}$ & I. 4 \\
\hline TO & 0.08 & 2.95 & 4.6 \\
\hline 20 & 0.92 & 6.6 & $7 \cdot I$ \\
\hline $5^{\circ}$ & $3 \cdot 3$ & 4.17 & 2.87 \\
\hline 100 & 0.64 & 0.23 & $0.2 \mathrm{I}$ \\
\hline \multicolumn{4}{|c|}{ (b) Enzyme plus albumin } \\
\hline IO & 0.45 & 0.49 & 0.55 \\
\hline 20 & I. 23 & I.05 & 1.09 \\
\hline 50 & 3.01 & 2.38 & 2.25 \\
\hline 100 & 3.66 & $3 \cdot 30$ & 4.92 \\
\hline
\end{tabular}


The order of addition of the substrates was important in determining the rate of the reaction (Table II). Addition of sn-glycerol 3-phosphate followed by acyl-CoA resulted in faster initial reaction rates than if the enzyme was allowed to interact with acyl-CoA before $s n$-glycerol 3 -phosphate was added. This effect of the order of addition of different substrates was altered when bovine serum albumin was present with the enzyme particles. In the presence of bovine serum albumin, the initial rate of reaction of acyl-CoA and sn-glycerol 3-phosphate was slower than when bovine serum albumin was not present.

\section{Inhibition of the enzyme by $N$-ethylmaleimide}

The enzyme is inhibited by incubation with $N$-ethylmaleimide. The inhibition can be overcome by prior incubation of enzyme with acyl-CoA (Table III). PalmitoylCoA, stearoyl-CoA and linoleoyl-CoA were all found to be effective in protecting the enzyme from $N$-ethylmaleimide inhibition. Concentrations of o.I mM $N$-ethylmaleimide gave about $90 \%$ inhibition of enzyme activity and prior incubation with acyl-CoA gave protection of about $90 \%$ of the enzyme activity.

\section{TABLE III}

REACTIVTY OF THE ENZYME AFTER TREATMENT WITH THYOL-BINDING REAGENTS AND PROTECTION BY PREINCUBATION WITH PALMITOYL-COA

\begin{tabular}{|c|c|c|}
\hline \multirow[t]{2}{*}{$\begin{array}{l}N-\text { Ethylmaleimide concn. } \\
(M)\end{array}$} & \multicolumn{2}{|c|}{$\begin{array}{l}\text { Reaction ( } \% \text { of control) } \\
\text { Preincubation conditions: }\end{array}$} \\
\hline & No palmitoyl-CoA & Palmitoyi-CoA \\
\hline \multicolumn{3}{|l|}{ Expt. $x$} \\
\hline $\begin{array}{l}5 \times 10^{-3} \\
5 \times 10^{-4} \\
5 \times 10^{-5} \\
5 \times 10^{-6} \\
\text { Control phosphatidate } \\
\text { formed in } 5 \text { min }\end{array}$ & $\begin{array}{l}0 \\
5 \\
14 \\
37 \\
1.2 \text { nmoles }\end{array}$ & $\begin{array}{r}0 \\
69 \\
100 \\
139\end{array}$ \\
\hline Expt. 2 & No stearoy-CoA & Stearoyl-CoA \\
\hline $\begin{array}{l}\text { I } \times \text { ro- } \\
\text { Control phosphatidate } \\
\text { formed in } 2 \text { min }\end{array}$ & 0.81 nmole & 83 \\
\hline
\end{tabular}

\section{$\left[{ }^{16} \mathrm{C}\right] \mathrm{N}$-Ethylmaleimide measurement of "protected" thiols}

Experiments were conducted to determine the properties and amount of the $N$-ethylmaleimide-sensitive acyltransferase. This was done by examining the thiol group that could be protected from $N$-ethylmaleimide binding by preincubation of the enzyme with acyl-CoA. The results are shown in Table IV. Preincubation of 50 $\mathrm{mg}$ of enzyme with 500 nmoles of stearoyl-CoA in a final volume of $5 \mathrm{ml}$ of $10 \mathrm{mM}$ Tris-maleate $(\mathrm{pH} 7.0$ ) for ro min was followed by treatment of aliquots of the protein with o,I $\mathrm{M} N$-ethylmaleimide. Controls were not treated with $N$-ethylmaleimide. The particles were centrifuged ( $140000 \times \mathrm{g}$ for $30 \mathrm{~min}$ ) through $0.25 \mathrm{M}$ sucrose at $0^{\circ}$. This washing procedure was adopted to remove $N$-ethylmaleimide from the treated aliquots. In these three experiments, preincubation with acyl-CoA prior to treatment with $N$-ethylmaleimide resulted in the protection of 43,42 and $31 \%$ of the enzyme activity measurable in particles that had been similarly preincubated 
TABLE IV

DETERMINATION OF THE AMOUNT OF THIOL GROUP ASSOCIATED WITH GLYCEROL PHOSPHATE ACYLTRANSFERASE

\begin{tabular}{|c|c|c|c|c|c|}
\hline \multicolumn{6}{|c|}{$\left[{ }^{14} \mathrm{C}\right] N$-Ethylmaleimide binding } \\
\hline \multicolumn{2}{|c|}{ Supernatant } & \multicolumn{2}{|l|}{ Pellet } & \multicolumn{2}{|l|}{ Total } \\
\hline${ }^{4} \mathrm{C}$ counts & $\begin{array}{l}\text { mmoles/ } \\
\text { mg protein }\end{array}$ & $\overline{\mathbf{1 4} C}$ connts & $\begin{array}{l}\text { moles/ } \\
\text { mg protein }\end{array}$ & $\overline{{ }^{14} \mathrm{C}}$ counts & $\begin{array}{l}\text { nmoles/ } \\
\text { mg protein }\end{array}$ \\
\hline
\end{tabular}

\begin{tabular}{|c|c|c|c|c|c|c|}
\hline \multicolumn{7}{|l|}{ Expt.I $(43 \%)$} \\
\hline $\begin{array}{l}\text { Incubated with } \\
\text { glycerol phosphate }\end{array}$ & 5575 & 0.46 & 5465 & 0.46 & I I $\mathrm{O}_{4}^{\circ}$ & 0.92 \\
\hline Incubated in the absence & & & & & & \\
\hline of glycerol phosphate & 3975 & 0.33 & $57^{20}$ & 0.48 & 9695 & $0.8 I$ \\
\hline Difference & 1600 & o.13 & -255 & -0.02 & I 345 & O.II \\
\hline Difference $\times 100 / 43$ & & 0.30 & & -0.04 & & 0.26 \\
\hline \multicolumn{7}{|l|}{ Expt. $2(42 \%)$} \\
\hline \multicolumn{7}{|l|}{$\begin{array}{l}\text { Difference between } \\
\text { incubating with and } \\
\text { without glycerol }\end{array}$} \\
\hline phosphate & $135^{\circ}$ & 0.06 & 890 & 0.04 & 2240 & 0.10 \\
\hline Difference $\times 100 / 4^{2}$ & & 0.14 & & 0.095 & & 0.24 \\
\hline \multicolumn{7}{|l|}{ Expt. $3(3 I \%)$} \\
\hline \multicolumn{7}{|l|}{$\begin{array}{l}\text { Difference between } \\
\text { incubating with and } \\
\text { without glycerol }\end{array}$} \\
\hline phosphate & 5650 & 0.076 & I 667 & 0.02 & 7317 & 0.096 \\
\hline Difference $\times 100 / 31$ & & 0.25 & & 0.06 & & $0.3 \mathrm{I}$ \\
\hline
\end{tabular}

with acyl-CoA but not treated with $N$-ethylmaleimide. The amount of protection by added acyl-CoA was less than that shown in Table III. This was probably due to the longer time of contact when the excess $N$-ethylmaleimide was removed by centrifugation in contrast to reacting it with dithiothreitol. After removal of excess unreacted $N$-ethylmaleimide, aliquots of the treated protein were incubated in the

TABLE V

EFFECT OF SONICATION WITH O.OI\% DEOXYCHOLATE ON THE DISTRIBUTION OF ENZYME ACTIVITY

The assay system had a final volume of $0.35 \mathrm{ml}$. It contained I $\mu$ mole of dithiothreitol, Ioo nmoles of $s n-\left[\mathrm{I}(3)-{ }^{14} \mathrm{C}\right]$ glycerol 3-phosphate, $20 \mu$ moles of Tris chloride ( $\mathrm{pH} 8.0$ ), either 9.6 or I4.4 nmoles of stearoyl-CoA and the indicated amount of protein was added to start the reaction. After 2 -min incubation at room temperature, $7 \mathrm{ml}$ of chloroform-methanol $2: \mathrm{I}, \mathrm{v} / \mathrm{v}$ was added. The $N$-ethylmaleimide-treated fractions were exposed at $25^{\circ}$ and pH 7.4 to $0.2 \mathrm{mM} N$-ethylmaleimide (400 nmoles of $N$-ethylmaleimide). $5 \mu$ moles of dithiothreitol were then added to combine with excess $N$-ethylmaleimide and the protein added to incubation mixtures as indicated. The observed rates of synthesis are expressed as a percent of the value obtained with intact microsomes.

\begin{tabular}{|c|c|c|c|c|c|c|c|c|c|c|}
\hline Protein present (mg): & $\begin{array}{l}\text { Origi- } \\
\text { nal } \\
\text { micro- } \\
\text { somes } \\
\text { I.I }\end{array}$ & $\begin{array}{l}\text { Soni- } \\
\text { cated } \\
\text { r.o }\end{array}$ & $\begin{array}{l}\text { (A) } \\
\text { Super- } \\
\text { natant } \\
\text { of } \\
\text { soni- } \\
\text { cated } \\
0.4\end{array}$ & $\begin{array}{l}\text { Pellet } \\
\text { of } \\
\text { soni- } \\
\text { cated } \\
0.6\end{array}$ & $A+B$ & $\begin{array}{l}\text { (C) } \\
N \text {-ethyl- } \\
\text { ma- } \\
\text { leimide } \\
\text { treated } \\
\text { super- } \\
\text { natant } \\
0.43\end{array}$ & $\begin{array}{l}\text { (D) } \\
N-\text { Ethyl } \\
\text { ma- } \\
\text { leimide } \\
\text { treated } \\
\text { pellet } \\
0.55\end{array}$ & $\begin{array}{l}B+C \\
l- \\
1.03\end{array}$ & $A+D$ & $C+D$ \\
\hline $\begin{array}{l}9.6 \text { nmoles stearoyl- } \\
\text { CoA }\end{array}$ & 100 & 88 & 77 & I 2 & 83 & 4 & $\mathbf{I}$ & 25 & $7^{\circ}$ & 7 \\
\hline $\begin{array}{l}\text { I } 4.4 \text { nmoles stearoyl- } \\
\text { CoA }\end{array}$ & 100 & 90 & 76 & 9 & 98 & Io & 0 & 29 & $7 \mathbf{I}$ & 5 \\
\hline
\end{tabular}


presence of $0 . \mathrm{I} \mathrm{mM}\left[{ }^{14} \mathrm{C}\right] N$-ethylmaleimide both with and without added $s n$-glycerol 3-phosphate. Previous protection studies showed that with this concentration of $N$-ethylmaleimide present in the reaction mixture only small amounts of phosphatidate were formed. After Io min, excess unreacted $N$-ethylmaleimide was allowed to react with dithiothreitol and the protein was washed free of low-molecular-weight ${ }^{14} \mathrm{C}$-labeled compounds by centrifuging ( $140000 \times g$ for $30 \mathrm{~min}$ ) through $0.25 \mathrm{M}$ sucrose. The protein pellet obtained after three such wash cycles was essentially free of low-molecular-weight ${ }^{14} \mathrm{C}$-labeled compounds as judged by centrifugation in sucrose and chromatography on Sephadex G-200. The protein pellet was suspended in $0.25 \mathrm{M}$ sucrose, I mM EDTA and $0.01 \%$ sodium deoxycholate and sonicated 3 times for I $5 \mathrm{sec}$ with a Branson sonifier $(8 \mathrm{~A})$. The mixture was centrifuged at $140000 \times g$ for $30 \mathrm{~min}$ to separate the solubilized and insoluble proteins. The counts in the supernatant and pellet were recorded. The greater change in $\left[{ }^{14} \mathrm{C}\right] \mathrm{N}$-ethylmaleimide binding after glycerol phosphate treatment occurred with the supernatant protein rather than the pellet. The enzyme activity of the sonicated fractions was measured in the standard glycerol phosphate incorporation assay procedure. These studies confirmed that most of the enzyme activity moved with the active thiol groups during this procedure (Table $V$ ). Thus, the enzyme was purified 2 -fold by sonication in the presence of $0.0 \mathrm{I} \%$ sodium deoxycholate. Further purification by gel filtration on Sephadex G-200 was attempted. However all the protein and enzyme activity eluted as one peak in the void volume. The activity measured in the supernatant was not enhanced by recombining it with either the $N$-ethylmaleimide treated or untreated protein from the pellet.

The amount of $\left[{ }^{14} \mathrm{C}\right] N$-ethylmaleimide that was bound to the enzyme fraction after treating the enzyme acyl-CoA complex with sn-glycerol 3-phosphate was about o.I nmole per $\mathrm{mg}$ of enzyme protein. This same protein fraction was capable of producing 0.66 nmole of diacyl-sn-glycerol 3-phosphate in the assay mixture in 2 min. Thus, the product formed in 2 min was already 6.6 times the amount of free thiol group determined by the $\left[{ }^{14} \mathrm{C}\right] \mathrm{N}$-ethylmaleimide labeling technique.

\section{The non-selectivity of acylation of different acyl groups}

When offered both stearoyl-CoA and linoleoyl-CoA in the incubation mixture, the enzyme did not show any selective incorporation of either acyl-CoA into the

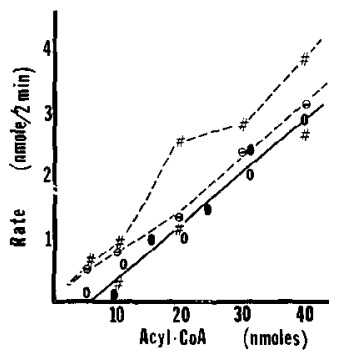

Fig. 4. Reaction rates of various acyl-CoA esters in the presence of $5 \mathrm{mg}$ of bovine serum albumin. The standard 2 -min assay with the addition of $5 \mathrm{mg}$ of bovine serum albumin was used. The final volume, $0.35 \mathrm{ml}$, contained $20 \mu$ moles of Tris chloride buffer (pH 8.o), I mg of enzyme protein, $5 \mathrm{mg}$ of bovine serum albumin, 100 nmoles of sn-glycerol 3-phosphate and various amounts of acyl-CoA as indicated: $-\longrightarrow$, oleoyl-CoA; $\Theta--\Theta$, linoleoyl-CoA; $0 \ldots-0$, stearoyl-CoA; \#- \#, lauroyl-CoA; 相- - \#, palmitoyl-CoA. 
I- or 2-positions of the glycerol molecule ${ }^{12}$. Using the system containing $\mathrm{I} \mathrm{mg}$ of particle protein with $5 \mathrm{mg}$ of bovine serum albumin in the $0.35 \mathrm{ml}$ assay mixture, there was no difference in the rate of incorporation of a variety of acyl-CoA esters (Fig. 4). This indicates a lack of specificity of the enzyme for the acyl portion of the acyl-CoA under the conditions of the experiment.

\section{DISCUSSION}

The nature of the product formed by the acylation of sn-glycerol 3-phosphate by particles from pigeon liver was determined to be diacyl-sn-glycerol 3-phosphate. This was shown using chromatography on silicic acid impregnated glass fibre paper, by catalytic hydrolysis of the phosphate group with chicken liver phosphohydrolase, and by identifying the major product as a diglyceride with only small amounts (about I0\%) present as monoglyceride. The product reported by FALLON AND $\mathrm{LAMB}^{2}$ from rat liver microsomes was identified as monoacyl-sn-glycerol 3-phosphate on the basis of chromatographic evidence in several systems. BRANDEs et al. ${ }^{11}$ have reported an acyl group to $s n$-glycerol 3-phosphate ratio of 1.3 , indicating the formation of a mixture of diacyl and monoacyl derivatives using rat liver microsomes. The ratio was not dependent upon a direct measure of acyl incorporation, but rather the increased amount of 260-m $\mu$ absorbance when glycerol phosphate was present. Such a measurement may give a minimal value when glycerol phosphate is present as a preferred acceptor relative to water. POSSMAYER et al. ${ }^{21}$ reported the formation of diacyl-sn-glycerol 3-phosphate by rat liver microsomes as did others ${ }^{12,22,24}$. In addition, guinea pig liver microsomes produced the diacyl derivative ${ }^{1,25}$, as did brain preparations $^{3}$. The presence of an enzyme in liver that is capable of acylating Iacylglycerol 3-phosphate ${ }^{\mathbf{9}, 22,23,25-27}$ makes an accumulation of the monoacyl derivative $^{2}$ hard to interpret.

The marked inhibition by acyl-CoA of the sn-glycerol 3-phosphate acyltransferase is characteristic of this activity isolated from all sources so far studied $\mathbf{2 , 4 , 6 , 9 , 2 8}$. This inhibition for the pigeon liver enzyme occurred above a palmitoyl-CoA concentration of about $60 \mu \mathrm{M}$ when I mg of enzyme protein was present in the reaction mixture. That level is also fairly near the value reported for the rat liver enzyme ${ }^{2}$ and the yeast enzyme ${ }^{6}$. Although enzyme inhibition by acyl-CoA is common, its cause is not clear, but is usually ascribed to the detergent properties of the substrate. The effect of acyl-CoA causing inhibition to several enzymes is well documented ${ }^{31-33}$ and the effect of adding extra protein in relieving this inhibition has been studied ${ }^{9,32,34}$. Adding different levels of particulate protein or bovine serum albumin raised the amount of palmitoyl-CoA that had to be added to the standard assay mixture before inhibition occurred. These data suggest that the physical form of the palmitoyl$\mathrm{CoA}^{29}$ is modified by the presence of the enzyme and the amount of the modification is dependent on the amount of protein present in the reaction mixture. It is likely that binding of acyl-CoA to protein reduces the effective concentration of palmitoylCoA below the critical micelle concentration ( $r$ ef. 30). Alternatively the presence of soluble protein could change the micellar formation of palmitoyl-CoA sufficiently to prevent inhibitory micellar formation before 20 nmoles are added to the reaction mixture. Evidence to support the idea that palmitoyl-CoA interacts with the protein is found in the change in the rate of reaction with the different order of addition 
of substrates (Table II). The initial rate of product formation was much slower when sn-glycerol 3-phosphate was added last. The possibility of hydrolysis of palmitoylCoA prior to addition of $5 n$-glycerol 3 -phosphate seems precluded by the observation that in the presence of $5 \mathrm{mg}$ of bovine serum albumin the rate of formation of phosphatidate was very similar no matter which order of addition of reagents is adopted.

The beneficial effect of adding acyl-CoA last raises the possibility that some functionally active site is slowly inactivated in the presence of high levels of substrate. One possible explanation considered was that the enzyme required a free prosthetic group essential to its transferase function, and that high concentrations of substrate kept it in the acylated form, preventing it from continued acyl transfer from CoA to glycerol phosphate. Presumably when glycerol phosphate is present first, the acyl groups are transferred to many more glycerol hydroxyls before the essential site of the enzyme becomes blocked. On the other hand, added albumin could bind substrate and slow the rate of the inactivating protein acylation. In such a case, the CoA thiol esters may have a greater tendency to form the "blocked" acylated transferase than other acyl donors such as acylated acyl-carrier protein. The speed of this reversible acyl inactivation could be considerably dependent on the acyl donor used.

The best acyl donor in experiments with $\mathrm{Cl}$. butyricum was shown to be acyl carrier protein by GOLDFINE et al. ${ }^{10}$. These workers believed that acyl CoA is not an intermediate in their system. In the $E$. coli system ${ }^{z}$, acyl-carrier protein also acts as acyl donor. Fatty acid, $\mathrm{ATP}, \mathrm{CoA}$ and $\mathrm{Mg}^{2+}$ were used in the plant system and the intervention of acyl-carrier protein was not described ${ }^{4,5}$, although acyl-carrier protein has been isolated from spinach leaves by Simoni et al. ${ }^{35}$. The acyl protein of the yeast fatty acid synthetase was found incapable of serving as an acyl donor unless CoA was added, presumably to serve in forming an acyl-CoA intermediate. In animal systems, acyl-carrier protein has not been isolated and the question whether the acyl-CoA first transfers the acyl group to a particle-bound acyl-carrier protein is not clear. However, the results with pigeon liver particles ${ }^{12}$ suggest that no appreciable reservoir of bound acyl groups are transferred to glycerol phosphate. When stearoyl-CoA, oleoyl-CoA or linoleoyl-CoA were incubated with particles only phosphatidates with 0,2 and 4 double bonds respectively were formed. This use of added acyl-CoA is in striking contrast to the situation reported for $\mathrm{Cl}$. butynicum ${ }^{10}$ where large amounts of endogenous acyl groups, presumably derived from acylated acyl-carrier protein are acylated to $s n$-glycerol 3 -phosphate. In that case, the actual acyl donors are not known, and there may be a variety of new substrates to examine as acyl donors.

We have shown that the thiol group essential for enzyme activity in the pigeon liver particulate fraction is not separated from the enzyme activity in sonication of the particles in $0.01 \%$ sodium deoxycholate (Tables IV and V). The amount of thiol group protected from $N$-ethylmaleimide binding by prior incubation of the enzyme with acyl-CoA has been estimated. $N$-ethylmaleimide combines with thiol groups on proteins ${ }^{37}$ but also reacts slowly with other groups ${ }^{38}$. This slow reaction with other groups could be partially responsible for the high blank values when $\left[{ }^{14} \mathrm{C}\right] \mathrm{N}$ ethylmaleimide is incubated with particles that had been treated earlier with nonisotopic $N$-ethylmaleimide without any prior protecting incubation with acyl-CoA. The amount of thiol groups present in the pigeon liver particles associated with $42 \%$ of the enzyme activity is, at maximum, 0 .I nmole per mg protein and could be less 
than this. The synthesis of phosphatidate in amounts 6.6 times greater than detectable bound sulfhydryl groups leads us to believe that the enzyme is capable of a turnover of acyl groups on the thiol group according to the following scheme.

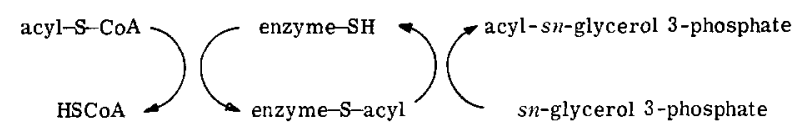

The need for rather high levels of acyl-CoA to protect the activity from $N$-ethylmaleimide may reflect the position of the equilibrium between the two thiol esters.

The turnover of acyl groups to the $N$-ethylmaleimide treated preparation would suggest that no additional catalytic thiol groups are needed other than those protected by the acyl-CoA. Thus, if an acyl-carrier protein did serve as the immediate acyl donor to glycerol phosphate, its ability to be recharged by acyl-CoA indicates that additional catalytic transferase thiol groups must also be protected for such turnover to occur. Those thiol groups are apparently concerned with only the first acylation of glycerol 3-phosphate, since the enzyme(s) calalyzing the second acylation function(s) adequately in the presence of $N$-ethylmaleimide and 5,5'-dithio-bis-(2-nitrobenzoic acid) ${ }^{9}$. Added protein from the insoluble (pellet) fraction that normally contains the other acyltransferase did not restore activity to the $N$-ethylmaleimide treated preparation (Table V). Further experiments with more highly purified fractions are needed to interpret the slight enhancement noted.

A low specificity for the yeast enzyme can be inferred from the finding of KuHn AND LYNEN ${ }^{6}$ that oleoyl-CoA protected the palmitoyl-CoA dependent incorporation of glycerol phosphate from $N$-ethylmaleimide poisoning and vice versa.

The enzyme activity of pigeon liver as isolated in vitro showed no specificity in its reaction with a variety of acyl-CoA derivatives under the conditions reported in this paper and reported by HiLl et al. ${ }^{12}$. POSSMAYER et al. ${ }^{21}$ have concluded that phosphatidate synthesis in rat liver microsomes in vitro occurred with positional specificity. Their system differed from that used in our experiments in that the acyl groups were presented as radioactive fatty acids. The labeled acids in the phosphatidate could arise by an acylation of some endogenous precursors and the different acids could be diluted by endogenous pools of different sizes making comparisons difficult. In our experiments the newly-formed phosphatidates were identified by the $\left[{ }^{14} \mathrm{C}\right]$ glycerol which could only have arisen by acylation of both hydroxy groups of sn-glycerol 3-phosphate. The lack of a specificity for acyl groups when studied in vitro was also reported in another laboratory recently ${ }^{24}$, and all these data reflect the original demonstrations of no $\mathrm{acyl}^{1}$ or positional $^{\mathbf{2 2}}$ specificity. If the enzyme system measured in vitro is responsible for the specific placement of saturated or unsaturated acyl groups at the I- and 2-positions in phosphatidates formed in the intact cell, the breakdown of the microenvironment with the disruption of the cell must remarkably change the properties of the enzyme system. This change may be due to the different protein concentrations and solvent conditions used when the cnzyme is assaycd in vitro. The presence of protein does markedly affect the properties of the enzyme particularly in regard to its behavior to varying acyl-CoA levels. The failure to observe specific placement of different acyl groups on the I- and 2-positions of $s n$-glycerol 3-phosphate may be due to the presentation of the acyl donors in the wrong form. The detergent effects of micellar acyl-CoA may alter the properties of 
the enzyme when assayed in vitro. Such effects would not be expected with physiological levels of protein or with acyl-carrier protein serving as the substrate. Alternatively, the provocative possibility remains that the enzyme system that is involved in phosphatidate synthesis in the intact cell may not be the same as that studied in vitro.

\section{REFERENCES}

I A. Korndberg and W. E. Prier, Jr., J. Biol. Chem., 204 (I953) 345.

2 H. J. FAllon AND R. G. LAMB, J. Lipid Res., 9 (Ig68) 652.

3 E. Mårtensson and J. Kanfer, J. Biol. Chem., 243 (1968) 497.

4 G. M. ChenïaE, Plant Physiol., 40 (I965) 235.

5 P. S. Sastry and M. Kates, Can. J. Biochem., 44 (1966) 459.

6 N. J. Kuhn and F. Lynen, Biochem. J., 94 (1965) 240.

7 G. P. Arlhaud and P. R. Vagkios, J. Biol. Chem, $2_{4} \mathrm{I}$ (1966) 3866.

8 H. Goldfine J. Biol. Chem., 24 I (1966) 3864 .

9 W. E. M. Lands and P. Hart, J, Biol. Chem., 240 (1965) 1905.

Io H. Goldfine, G. P. Ailhaud and P. R. Vagelos J. Biol. Chem., 242 (1967) 4466.

i R. Brandes, J. Olley and B. Shapiro, Biochem. $J ., 86$ (1963) 244.

I 2 E. E. Hill, D. R. Husbands AND W. E. M. Lands, J. Biol. Chem., 243 (1968) 4440.

I3 H.-J. Hohorst in H. U, Bergmeyer, Methods in Enzymatic Analysis, Academic Press, New York, 1965, p. 215.

I4 W. C. MoMurray, K. P. Strickland, J. F. Berre and R. J. Rosstter, Biochem. J., 66 (I957) 634.

I5 W. E. M. Lands, J. L. Blank, L. J. Nutter and O. S. Prtvett, Lipids, I (1966) I.

I6 W. Sevbert, Biochem. Prep., 7 (1960) 8o.

I 7 O. Warburg and W. Christian, Biochem. $Z$., $310\left(\mathrm{fg}^{2}\right) 3^{8} 4$.

I 8 F. SNyder, Anal. Biochem., 9 (1964) I 83.

ig S. W. Smrth, S. B. Weiss and E. P. Kennedy, J. Biol. Chem., 228 (r957) 915.

20 R. Tzur, E. Tal and B. Shapiro Biochim. Biophys. Acta, 84 (1964) I 8.

2 F. Possmayer, G. L. Scherphof, T. M. A. R. Dubbelman, L. M. G. Van Golde and L. L. M. VAN DEENEN, Biochim. Biophys, Acta, 176 (rg69) 95 .

22 W. E. M. LANDS AND P. HART, J. Lipid Res., 5 (1964) 8I.

23 W. Stoffel and H. G. Schtefer, Z. Physiol. Chem., 349 (1968) 1oI7.

24 H. M. Abou-Issa and W. W. Cleland, Biochim. Biophys. Acta, 176 (rg69) 692.

25 W. Stoffel, M. E. Tomas and H.-G. Schiefer, 2 . Physiol. Chem., 348 (1967) 882.

26 E. E. Hill and W. E. M. Lands, Biochim. Biophys. Acta, 152 (rg68) 645.

27 R. E. Barden and W. W. Cleland, J. Biol. Chem., 244 (r969) 3677.

28 N. J. KUн, Biochem. J., I05 (1967) 213.

29 W. L. Zahler and W. W. Cleland, Biochim. Biophys. Acta, I76 (rg69) 699.

3o W. L. Zahler, R. E. Barden and W. W. Cleland, Biochim. Biophys. Acta, 164 (rg68) I.

3 I O. WIELANd, L. WeISs, AND 1. Eger-NeUfeldt, Advan. Enzyme Regulations, 2 (I964) 324.

32 K. Taketa and B. M. Pogelt, $J$. Biol. Chem., 24 I (1966) 720.

33 S. V. Pande and J. F. Mead, J. Biol. Chem., 243 (1968) 6r80.

34 R. Tzur and B. Shapiro, J. Lipid Res., 5 (I964) 542.

35 R. D. Simont, R. S. Cridde ANd P. K. STUMPF, J. Biol. Chem., 242 (1967) 573.

36 N. J. KUHN, Biochem. J., 105 (1967) 213.

37 J. D. Gregory, J. Am. Chem. Soc, 77 (1955) 3922.

38 D. G. Smyth, A. Nagamatsu and J.S. Fruton, J. Am. Chem. Soc., 82 (1960) 4600.

Biochim. Biophys. Acta, 202 (1970) 129-140 